\title{
Механизм резистивных переключений в пленках на основе частично фторированного графена
}

\author{
(С) А.И. Иванов ${ }^{1}$, Н.А. Небогатикова ${ }^{1}$, И.И. Куркина ${ }^{2}$, И.В. Антонова ${ }^{1,3,4}$ \\ ${ }^{1}$ Институт фризики полупроводников им. А.В. Ржанова \\ Сибирского отделения Российской академии наук, \\ 630090 Новосибирск, Россия \\ ${ }^{2}$ Северо-Восточный фредеральный университет им. М.К. Аммосова, \\ 677000 Якутск, Россия \\ ${ }^{3}$ Новосибирский государственный университет, \\ 630090 Новосибирск, Россия \\ ${ }^{4}$ Новосибирский государственный технический университет, \\ 630073 Новосибирск, Россия \\ E-mail: aiivanov@isp.nsc.ru
}

(Получена 27 декабря 2016 г. Принята к печати 17 февраля 2017 г.)

\begin{abstract}
Исследован механизм резистивных переключений в пленках частично фторированного графена. Пленки были получены на основе ряда графеновых суспензий с разным составом и различной степенью фторирования. Экспериментально обнаружена зависимость величины резистивных переключений от наличия в составе суспензии органических добавок ( $N$-метилпирролидон и диметилформамид) и степени фторирования. Показано, что для пленок, полученных из суспензии без органических составляющих, резистивные переключения не наблюдаются вне зависимости от степени фторирования. Максимальный эффект, 10-20 раз, обнаружен для пленок, содержащих диметилформамид. Предложена физическая модель пленок, согласно которой наблюдаемая зависимость связана с наличием в исследованных пленках капсулированных функциональных групп, образованных из молекул диметилформамида, проявляющих электрическую активность. Измеренные вольт-амперные характеристики пленок наилучшим образом описываются моделью Френкеля-Пула с энергией активации центров 0.08 эВ, ответственных за проводимость. Величина переключений зависит от степени фторирования исходных суспензий. Максимальный эффект наблюдается при степени фторирования суспензии $\sim C F_{0.25}$. Исследованные в работе суспензии частично фторированного графена подходят для создания приборных структур при помощи 2D-печати.
\end{abstract}

DOI: 10.21883/FTP.2017.10.45013.8498

\section{1. Введение}

Гибкая электроника - это недавно возникшая и интенсивно развивающаяся область современной электроники, которая вызывает все больший научно-технический интерес [1]. Методы, используемые при создании устройств гибкой электроники, например 2D-печать, позволяют создавать структуры на гибких и жестких подложках, большой площади, и, что немаловажно, с низкой стоимостью. Тем не менее производительность таких устройств и их свойства ограничены качеством используемых материалов, и прежде всего органических материалов [2,3]. В связи с этим графен как материал, обладающий уникальными физическими свойствами [4], и материалы, полученные на его основе, открывают возможности преодоления многих технологических ограничений. Особый интерес представляет создание печатных устройств памяти, одним из перспективных направлений считается резистивная память из материалов на основе графена. Существует ряд работ, описывающих резистивные переключения в пленках оксида графена [5-7], но это нестабильный материал и устройства на его основе, скорее всего, будут недолговечны.

Фторированный графен (ФГ) - диэлектрик с величиной запрещенной зоны $\sim 3$ эВ [8], который является более стабильным соединением графена. Не так давно нами была разработана технология фторирования графена в растворах плавиковой кислоты [9], позволившая изготавливать фторированный графен в объемах, достаточных для создания приборных структур, используя, например, 2D-печать. Совсем недавно вышла работа по исследованию электрических характеристик фторированного графена, и оказалось, что на вольтамперных характеристиках для пленок этого материала наблюдаются резистивные переключения [10]. Преимуществом резистивной памяти на основе пленок фторированного графена являются стабильность данного материала и возможность создания пленок на твердых и гибких подложках, при комнатной температуpe [11]. Но стабильность фторографена означает необходимость введения второй фазы, с которой и будут связаны резистивные переключения. Так, резистивные переключения обнаружены в двухфазных композитных системах полимер-графен или полимер-оксид графена, содержащих графен в концентрации, превышающей порог возникновения перколяционной проводимости $[12,13]$.

В настоящей работе рассмотрен эффект резистивных переключений, наблюдаемый в пленках частично фторированного графена. Изученные в работе пленки были 


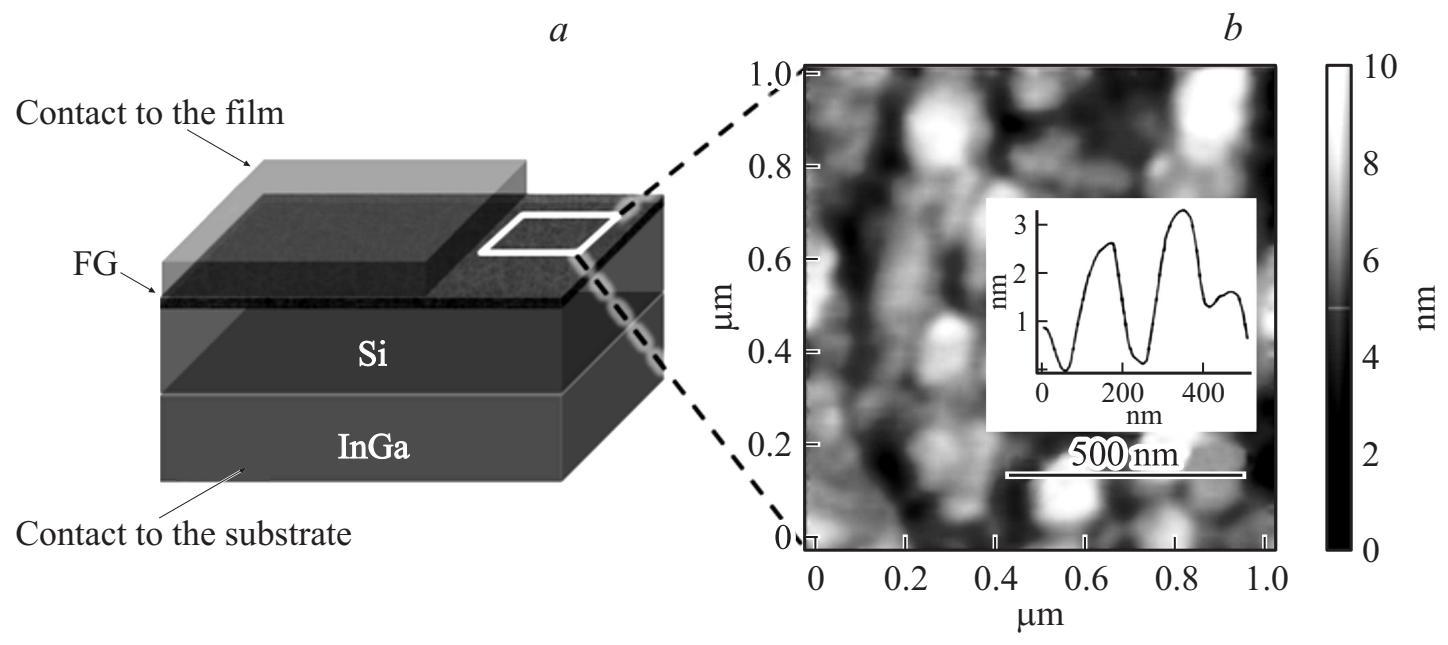

Рис. 1. $a-$ схематичное изображение структуры образцов; $b-$ АСМ-изображение поверхности пленки. На вставке к рис. $1, b$ показан характерный рельеф поверхности.

получены из ряда суспензий, не содержащих никаких добавок, либо содержащих $N$-метилпирролидон (NMP), или диметилформамид (DMF). Проведено исследование механизма резистивных переключений.

\section{2. Материалы и методы исследований}

В качестве основного материала использовался частично фторированный графен, полученный путем функционализации графеновой суспензии в слабом растворе плавиковой кислоты $[9,14]$. Суспензия графена была создана диспергированием порошка графита в воде либо без добавок, либо с добавлением органических растворителей. В работе были созданы и исследованы три типа суспензий: 1) содержащая в качестве органической добавки DMF суспензия, называемая далее в тексте статьи как FG-1; 2) суспензия с NMP - FG-2; 3) без добавления органических компонентов - FG-3 (электрохимическое расслоение графита). Органические молекулы интеркалировали между слоями графита, что способствовало ускорению процесса его расслоения при последующих обработках суспензий ультразвуком [14]. На следующем после создания этапе полученные суспензии смешивались с раствором плавиковой кислоты, и начинался процесс фторирования графеновых чешуек, находящихся в суспензиях.

Пленки создавались путем нанесения капель суспензий на поверхность кремниевой подложки. На рис. 1, $a$ схематично изображена структура, используемая для исследования электрических характеристик пленок. На рис. 1, $b$ показано АСМ-изображение поверхности пленки фторированного графена, на вставке к рисунку показан характерный профиль рельефа поверхности. Толщина чешуек фторированного графена составляет $\sim 1-2$ нм. Толщина созданных для исследований пленок находилась в диапазоне 90-100 нм. В ходе работы были получены 3 типа пленок, обозначенные по номеру использованных суспензий: FG-1, FG-2 и FG-3. После высыхания пленки промывались в воде с целью удаления избытков органических добавок.

Для проведения измерений электрических характеристик на поверхности пленок фторированного графена создавались контакты. Контакты формировались либо путем нанесения серебряной пасты, либо напылением золота (рис. 1,a). На нижней поверхности кремниевой пластины создавался второй контакт из InGa-пасты (рис. 1,a). Измерения вольт-амперных характеристик при комнатной температуре проводились с использованием пикоамперметра Keithley (model 6485). Для получения информация о поверхности структуры и толщине пленок был использован метод атомносиловой микроскопии (ACM). Изображения поверхности были получены при помощи микроскопа Solver PRONT-MDT. Для сканирования были использованы контактный и полуконтактный режимы работы микроскопа. Исследования температурной зависимости проводимости пленок проводились в диапазоне температур от комнатной $330 \mathrm{~K}$ до температуры жидкого азота $78 \mathrm{~K}$. Для измерения и записи вольт-амперных характеристик в зависимости от температуры была использована специализированная установка Asec17. Измерения характеристик проводились в закрытом держателе в условиях отсутствия подсветки исследуемых образцов.

\section{3. Экспериментальные результаты}

Для исследования зависимости величины эффекта резистивных переключений от различных факторов было изучено влияние материала контактов, состава и степени функционализации суспензий. Степень фторирования 

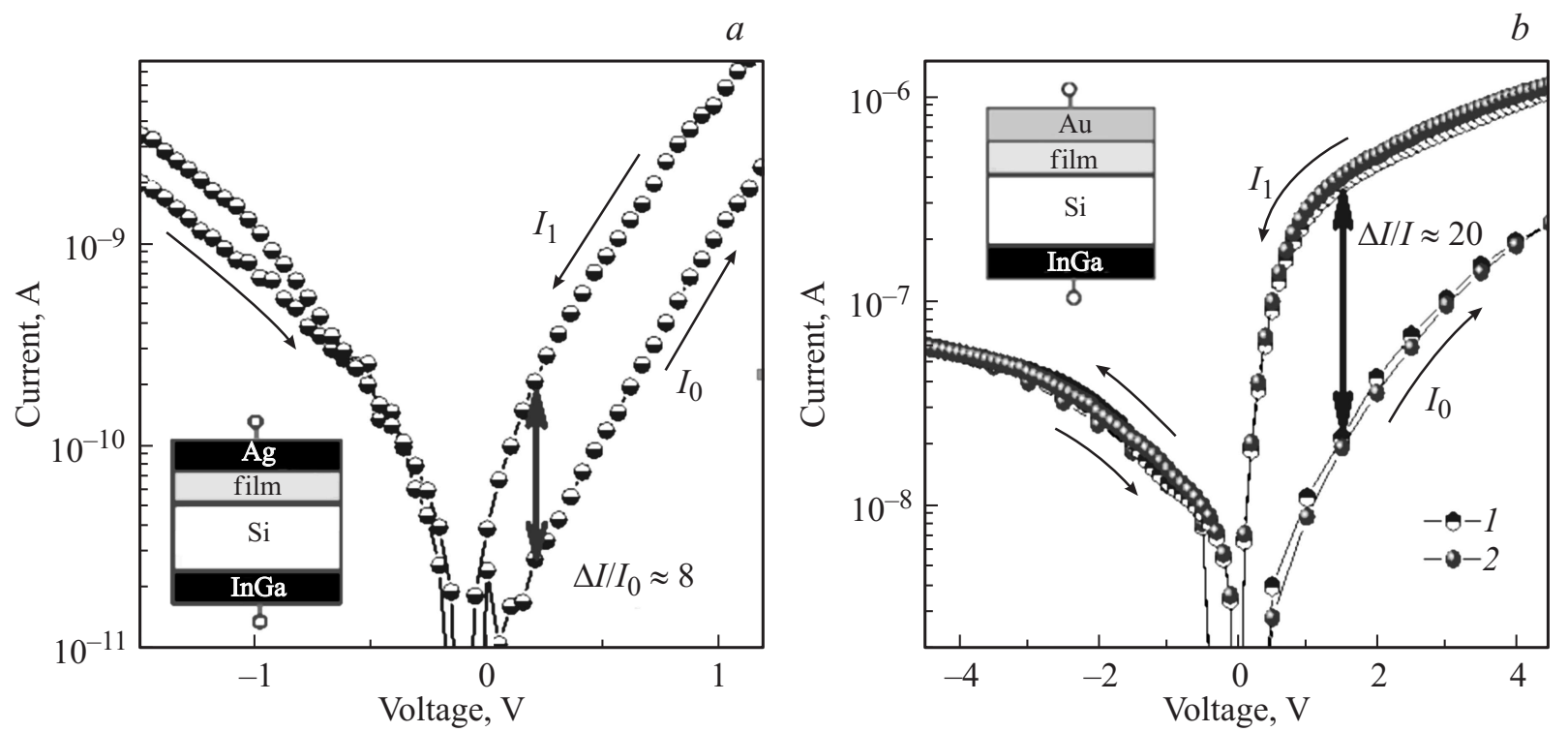

Рис. 2. Вольт-амперная характеристика (ВАХ) образцов, записанная для двух направлений развертки напряжения: $a-$ контакт к пленке изготовлен из серебряной пасты, $b-$ контакт к пленке изготовлен из золота. Стрелками указано направление развертки напряжения. $I_{0}-$ ток в высокоомном состоянии, $I_{1}-$ ток низкоомном состоянии.

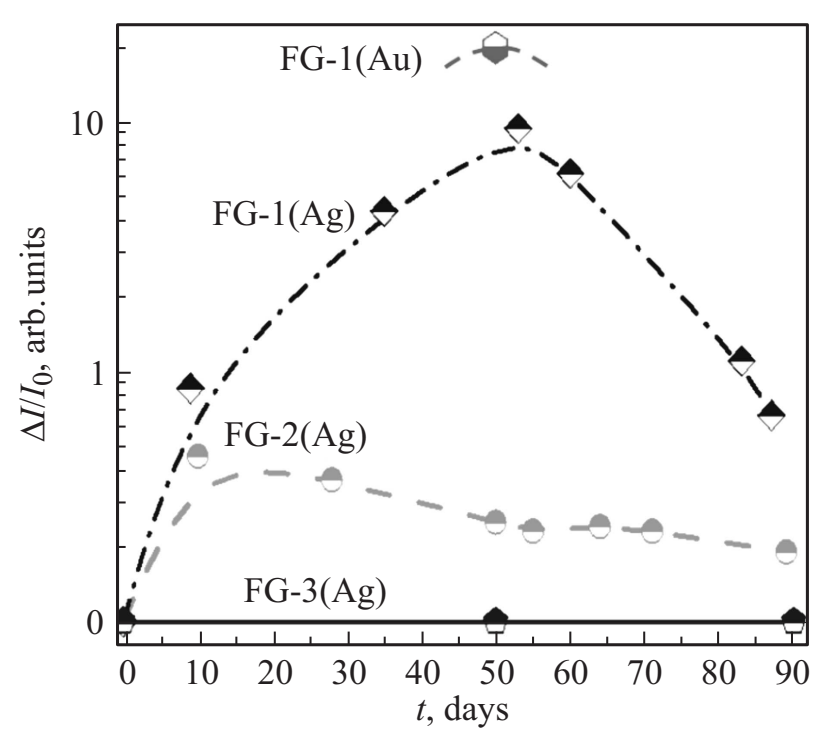

Рис. 3. Влияние состава исходных суспензий на величину резистивных переключений для пленок из фторированного графена FG-1(DMF), FG-2 (NMP), FG-3 (без добавок).

пленок изменялась по мере увеличения продолжительности фторирования суспензий. На рис. 2 показаны вольт-амперные характеристики для структур, различающихся только материалом контактов. Сопротивления, полученные для низкоомного $\left(R_{1}\right)$ и высокоомного $\left(R_{0}\right)$ состояний, отличаются в $\sim 8$ раз для серебряных контактов и в $\sim 20$ раз для золотых контактов.

Исследование влияния органических веществ на величину резистивных переключений представлено на рис. 3 . Верхняя кривая отражает величины эффекта, получен- ные для пленок, содержащих DMF (FG-1), средняя NMP (FG-2), нижняя зависимость соответствует структурам, не содержащим органики (FG-3). В скобках указан материал, использованный для создания контактов. Максимальный эффект переключений наблюдался для пленок, содержащих DMF.

Максимальный эффект резистивных переключений был получен на пленках FG-1, фторированных на протяжении 50-60 дней. Согласно данным XPS [14], степень фторирования таких пленок составляет $\mathrm{CF}_{0.25}$. Вольтамперные характеристики для данных структур представлены на рис. 4. Из анализа измерений следует, что эффект резистивных переключений появляется при $U \sim 1.6$ В. Максимальный эффект наблюдается при напряжениях в диапазоне $U \sim 1.9-2$ В. Когда приложенное напряжение превышает 2 В, гистерезис уменьшается и ток выходит на насыщение. Многократные повторные измерения (100-200 измерений на разных структурах) показали стабильность резистивных переключений в данном материале.

Следуя классификации резистивных переключений, представленной в работе [15], наблюдаемые вольтамперные характеристики можно отнести к нелинейному биполярному эффекту. Особенность характеристик заключается в том, что при $U<0$ гистерезис имеет незначительную величину. Одна из причин - влияние дневного света, который, как показано в [16], уменьшает величину резистивных переключений.

Для пленок в низкоомном состоянии была измерена температурная зависимость вертикальной проводимости в диапазоне температур 78-330 K (рис. 5). Изменение тока через пленки может быть описано соотношением 
$I(T)=I_{0} \exp (-E / k T)$, где $E-$ энергия активации активных центров, а $k$ - постоянная Больцмана. В температурном диапазоне от 150 до $330 \mathrm{~K}$ энергия активации составляет $\sim 0.09$ эВ. При $T<150 \mathrm{~K}$ ток практически перестает зависеть от температуры.
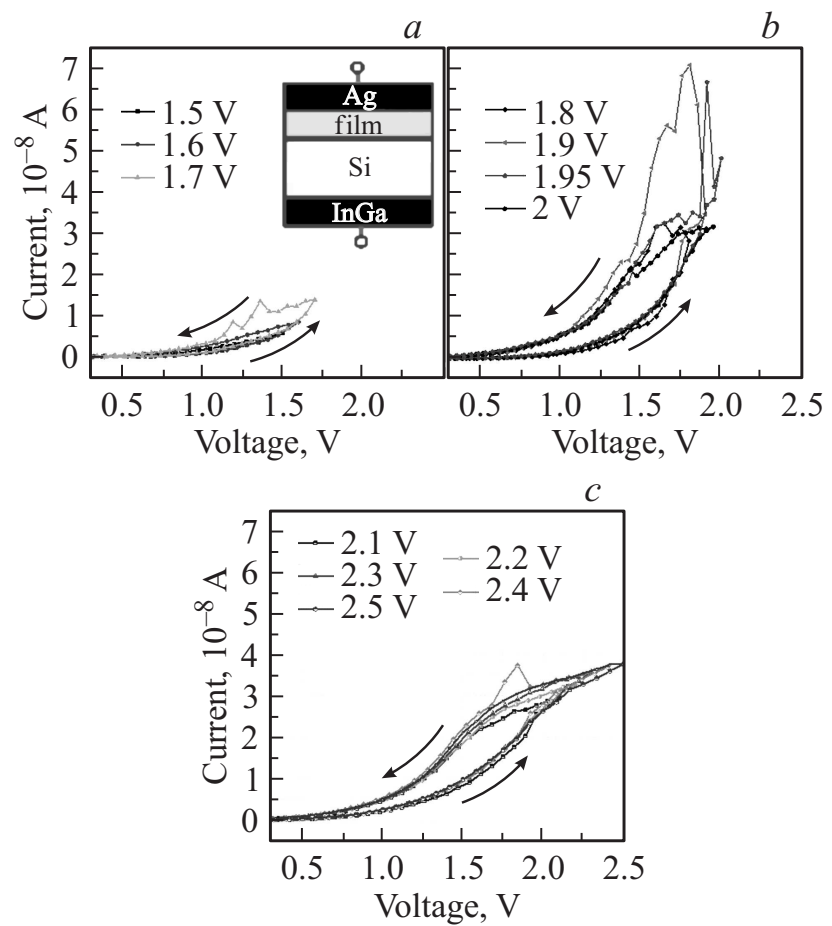

Рис. 4. Вольт-амперные характеристики пленки FG-1, полученной из суспензии после 50 дней фторирования. Представленные измерения ВАХ разделены на три группы и показаны с последовательным увеличением величины прикладываемого напряжения $U: a)$ напряжения $1.5-1.7 \mathrm{~B}-$ появление эффекта резистивных переключений, $b$ ) напряжения $1.8-2 \mathrm{~B}-$ диапазон, в котором наблюдался максимальный гистерезис, c) напряжения 2.1-2.5 В - насыщение эффекта резистивных переключений.

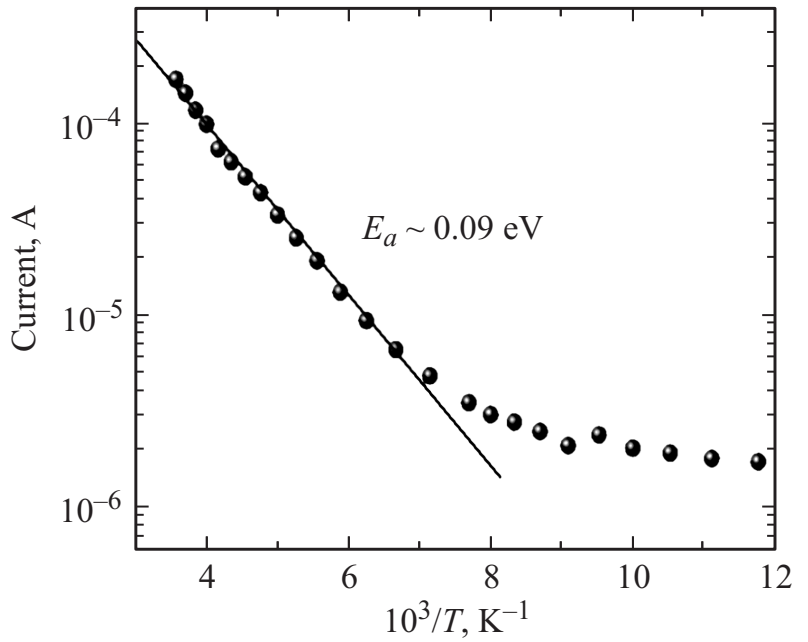

Рис. 5. Температурная зависимость проводимости пленки фторированного графена, содержащей следы DMF. Величина энергии активации $E_{a}$ составляет $\sim 0.09$ эВ.

\section{4. Обсуждение}

Для исследования механизма изменения сопротивления специально было проведено сравнение пленок на основе частично фторированных суспензий, содержащих органические добавки и без них. Было показано, что для появления эффекта резистивных переключений наличие в составе пленок и исходных суспензий органических добавок принципиально необходимо. В случае подобных композитных пленок полимеров с частицами графена или оксида графена эффект резистивных переключений в значительной степени связан со структурными окислительно-восстановительными процессами в частицах Gr или GO [12]. Механизм переключения и памяти в таких системах авторы связывают с присутствием вакансий кислорода и электронных ловушек в частицах GO, формирующих проводящий канал, а также с процессами захвата и накопления носителей заряда частицами оксида графена или графена в полимерной матрице. Значительное дополнительное влияние могут оказывать также электронно-тепловые механизмы [13]. Мы предполагаем, что изменение сопротивления в наших исследованных пленках частично фторированного графена связано с наличием в составе пленок функциональных групп, формирующихся из молекул DMF и $\mathrm{NMP}$, и проявлением ими электрической активности, поскольку атомы фтора образуют стабильную связь с атомами углерода, и их активность, обусловленная внешними воздействиями, гораздо ниже по сравнению с кислородсодержащими функциональными группами на поверхности графена. Перезарядка этих электрически активных центров (функциональных групп) вызвана приложенным напряжением и связана с ионизацией функциональных групп. Разнообразие функциональных групп, образуемых из молекулы DMF, показано на рис. 6. B результате реакции DMF с водой образуется формиат (группа: $\mathrm{HCOO}-$ ), энергия активации которого составляет 7.4 кДж $\cdot$ моль $^{-1}[17]$, что соответствует $\sim 77$ мэВ (рис. 6,a). Также было обнаружено, что в спектре Рамана для пленки частично фторированного графена (рис. 6,b), содержащего следы DMF в незначительной концентрации, присутствуют пики, характерные для формиата [18]. В целом, по-видимому, функциональные группы и частицы фторированного графена образуют двухфазную систему, демонстрирующую стабильные резистивные переключения.

Вольт-амперные характеристики образцов, которые демонстрировали максимальный эффект резистивных переключений, были изучены с целью выяснения механизма, ответственного за перенос тока в пленках. Были рассмотрены механизмы Шоттки, Фаулера-Нордгейма, тока, ограниченного пространственным зарядом (ТОП3), и Френкеля-Пула. Как оказалось, наилучшим образом зависимость тока от напряжения (рис. 4,b) может быть описана в терминах механизма Френкеля- 

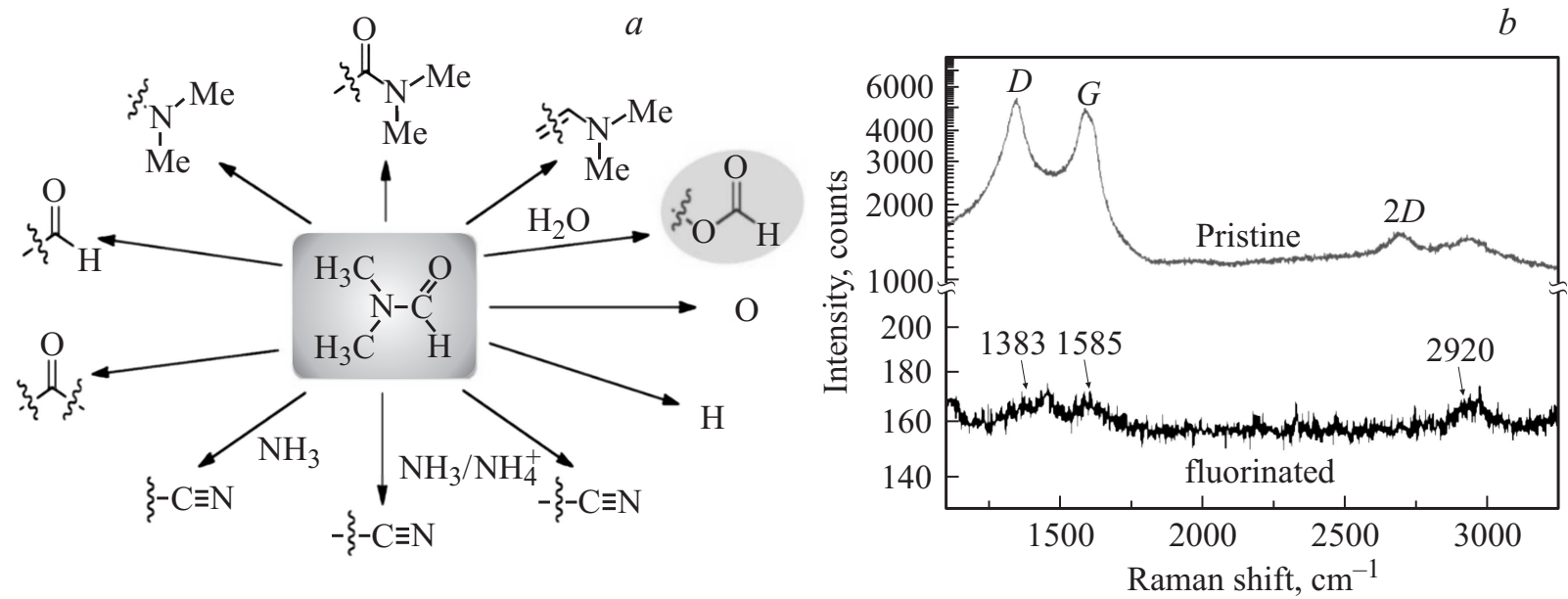

Рис. 6. $a$ - многообразие функциональных групп, образуемых диметилформамидом (DMF) $[19], b$ - спектр Рамана для пленки частично фторированного графена.
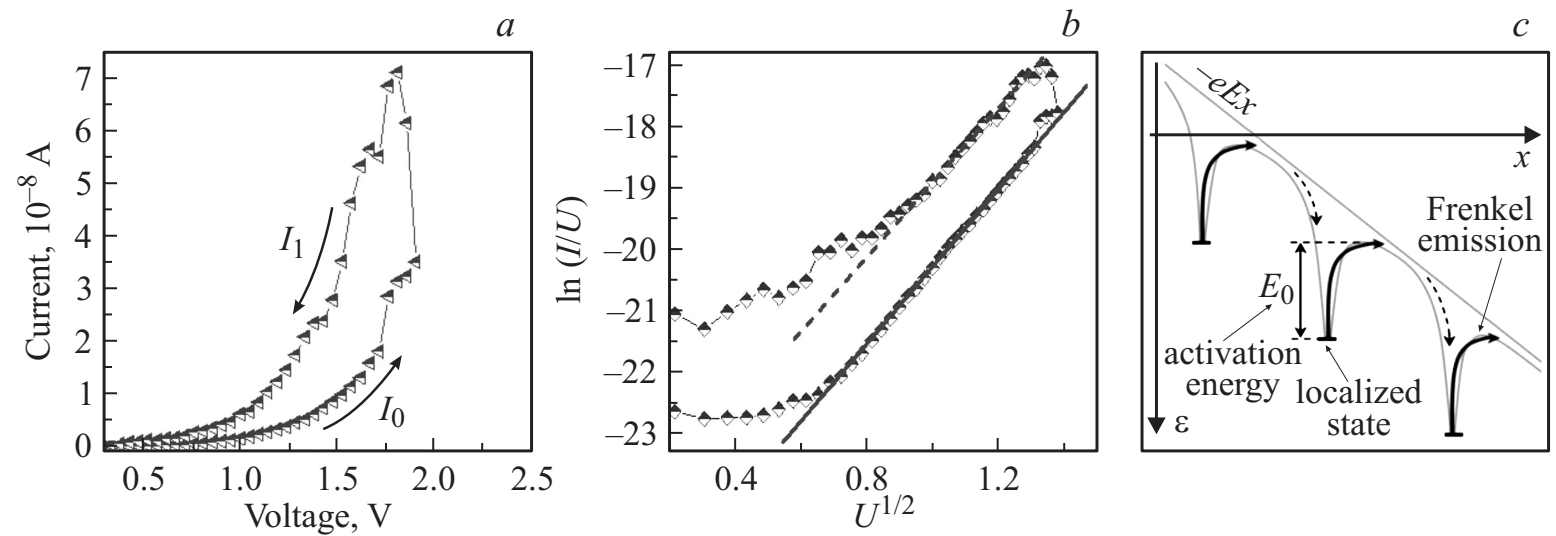

Рис. 7. Анализ механизма резистивных переключений в пленке фторированного графена FG-1. $a$ - вольт-амперная характеристика пленки, построенная в стандартных осях, $R_{0}=420 \mathrm{MOм,} R_{1}=54$ МОм. $b-$ вольт-амперная характеристика пленки, построенная в координатных осях $\ln (I / U), U^{1 / 2} . c-$ схематичное изображение проводимости по механизму Френкеля-Пула для фторированного графена с электрически активными центрами в запрещенной зоне.

Пула [20-24]:

$$
I=e \mu n E \exp \left(\frac{\beta E^{\frac{1}{2}}}{r k_{\mathrm{B}} T}\right),
$$

где $e, \mu, n-$ заряд, подвижность и концентрация электронов соответственно; $k_{\mathrm{B}}-$ постоянная Больцмана, $E-$ напряженность поля, создаваемая разностью потенциалов на контактах структуры; $\beta=\left(\frac{e^{3}}{\pi \varepsilon \varepsilon_{0}}\right)^{\frac{1}{2}}-$ постоянная Френкеля-Пула, произведение $\beta E^{\frac{1}{2}}$ учитывает понижение высоты потенциального барьера, создаваемого примесным центром в модели Френкеля-Пула, в зависимости от величины поля; $r=1+\frac{k_{\mathrm{B}} T}{E_{0}}-$ коэффициент, учитывающий характерную энергию электрически активных центров. В случае исследованных в работе пленок примесными центрами являются электрически активные центры, образованные функциональными группами.
Из вольт-амперных характеристик пленки FG-1 была выбрана кривая, соответствующая максимальному эффекту переключений (рис. 7,a), и построена в координатных осях $\lg (I / U)$ от $U^{1 / 2}$, в которых, в случае присутствия механизма проводимости Френкеля-Пула, характеристики должны иметь линейные участки (рис. 7, $b$ ). Схематичное изображение проводимости, описываемой механизмом Френкеля-Пула показано на рис. 7, $c$.

Для вольт-амперной характеристики, демонстрирующей максимальные резистивные переключения (рис. $5, b)$, был определен коэффициент наклона, описываемый формулой

$$
k=\operatorname{tg}(\theta)=\frac{\Delta y}{\Delta x} .
$$

Учитывая, что

$$
\lg (\sigma) \approx \lg \left(\frac{I}{U}\right) \approx \frac{\beta E^{\frac{1}{2}}}{r k_{\mathrm{B}} T}=\frac{\beta U^{\frac{1}{2}}}{r k_{\mathrm{B}} T L^{\frac{1}{2}}},
$$


коэффициент наклона можно записать в виде

$$
k=\frac{\beta}{r k_{\mathrm{B}} T L^{\frac{1}{2}}},
$$

где $L$ - толщина пленки.

С учетом толщины пленки $L$, равной 90-100 нм, была рассчитана энергия активации примесных центров и получено значение $E_{0} \sim 0.07-0.08$ эВ. Вычисленная величина близка к величине активации 0.08 эВ, определенной методами зарядовой спектроскопии глубоких уровней Q-DLTS [16] и из анализа температурной зависимости токов для пленок частично фторированного графена на основе DMF, содержащей суспензии (0.09 эB).

\section{5. Заключение}

В работе рассмотрены перспективные для приложений пленки частично фторированного графена, созданные на основе графеновых суспензий и демонстрирующие эффект резистивного переключения. Показано, что величина резистивного эффекта в исследованных пленках существенно зависит от степени фторирования суспензии и от типа органических добавок, использованных при ее получении. Исследованы условия необходимые для принципиального появления эффекта и достижения его максимума. Максимальное отношение токов $I_{1} / I_{0} \sim 10$ наблюдалось для пленок на основе суспензий с демитилформамидом. Напряжение переключения между разными состояниями пленок составляло 1.5-2 В. В случае отсутствия в составе суспензии фторированного графена органических добавок переключений между состояниями $I_{0}$ и $I_{1}$ для исследованных пленок не наблюдалось. Предложен механизм резистивных переключений, связанный с наличием в пленках частично фторированного графена электрически активных центров. Возможное происхождение таких центров - капсулирование между отдельными частицами фторированного графена функциональных групп, образовавшихся из молекул органических добавок в процессе фторирования графеновой суспензии. Предложена модель изменения проводимости пленок. Наилучшим образом зависимость проводимости описывается моделью Френкеля-Пула, энергия активации электрически активных центров составляет $\sim 0.08$ эВ. Изученные в работе суспензии фторированного графена благодаря демонстрируемым свойствам и характеристикам обладают большим потенциалом в области 2D-печати для создания приборных структур связи.

Работа выполнена при поддержке РФФИ, грант № 15-02-02189.

\section{Список литературы}

[1] Y. Gao, W. Shi, W. Wang, Y. Leng, Y. Zhao. Ind. Eng. Chem. Res., 53, 16777 (2014).

[2] M. Magliulo, M.Y. Mulla, M. Singh, E. Macchia, A. Tiwari, L. Torsi, K. Manoli. J. Mater. Chem. C, 3, 12347 (2015).
[3] L. Huang, Y. Huang, J. Liang, X. Wan, Y. Chen. Nano Res., 4, 675 (2011).

[4] Z. Jing, Z. Guang-Yu, S. Dong-Xia. Chin. Phys. B, 22, 057701 (2013).

[5] C.C. Lin , H.Y. Wu, N.C. Lin, C.H. Lin. Jpn. J. App. Phys., 53, 05FD03 (2014).

[6] H.Y. Jeong, J.Y. Kim, J.W. Kim, J.O. Hwang, J.E. Kim, J.Y. Lee, T.H. Yoon, B.J. Cho, S.O. Kim, R.S. Ruoff., S.Y. Choi. Nano Lett., 10, 4381 (2010).

[7] B. Standley, A. Mendez, E. Schmidgall, M. Bockrath. Nano Lett., 12, 1165 (2012).

[8] N.A. Nebogatikova, I.V. Antonova, V.A. Volodin, V.Ya. Prinz. Physica E., 52, 106 (2013).

[9] N.A. Nebogatikova, I.V. Antonova, V.Ya. Prinz, V.A. Volodin, D.A. Zatsepin, E.Z. Kurmaev, I.S. Zhidkov, S.O. Cholakh. Nanotechnol. Russ., 9, 51 (2014).

[10] I. Kurkina, I.V. Antonova, N.A. Nebogatikova, A.N. Kapitonov, S.A. Smagulova. J. Phys. D: Appl. Phys., 49, 095303 (2016).

[11] И.В. Антонова, И.А. Котин, В.И. Попов, Ф.Д. Васильева, А.Н. Капитонов, С.А. Смагулова. ФТП, 50, 1086 (2016).

[12] П.С. Крылов, А.С. Берестенников, А.С. Фефелов, А.С. Комолов, А.Н. Алешин. ФТТ, 58, 2476 (2016).

[13] П.С. Крылов, А.С. Берестенников, А.Н. Алешин, А.С. Комолов, И.П. Щербаков, В.Н. Петров, И.Н. Трапезникова. ФTT, 57, 1639 (2015).

[14] N.A. Nebogatikova, I.V. Antonova, V.Ya. Prinz, I.I. Kurkina, V.I. Vdovin, G.N. Aleksandrov, V.B. Timofeev, S.A. Smagulova, E.R. Zakirova, V.G. Keslera. Phys. Chem. Chem. Phys., 17, 13257 (2015).

[15] J.J. Yang, D.B. Strukov, D.R. Stewart. Nat. Nanotechol., 8, 13 (2013).

[16] I.I. Kurkina, I.V. Antonova, N.A. Nebogatikova, A.N. Kapitonov, S.A. Smagulova. J. Phys. D: Appl. Phys., 49, 095303 (2016).

[17] M. Chaumontet, R. Piccardi, N. Audic, J. Hitce, J.L. Peglion, E. Clot, O. Baudoin. J. Am. Chem. Soc., 130, 15157 (2008).

[18] A.J. Mcquillan, C.G. Pope. Chem. Phys. Lett., 71, 349 (1980).

[19] S. Ding, N. Jiao. Angew. Chem. Int. Ed., 51, 9226 (2012).

[20] Я.И. Френкель. Собр. избр. тр. Т. 2. Научные статьи (М., Наука, 1958) гл. 13, с. 217.

[21] R.M. Hill. Phil. Mag., 24, 1307 (1971).

[22] В.Н. Абакумов, В.И. Перель, И.Н. Яссиевич. Безызлучательная рекомбинация в полупроводниках (СПб., ПИЯФ, 1997) гл. 10, с. 200.

[23] В. Малиненко, О. Сергеева. Зонный и прыжкковый механизмы переноса в неупорядоченных оксидах металлов: Метод. указания к лаб. работе (Петрозаводск, ПетрГУ, 2002).

[24] П.А. Райкерус, В.А. Лалеко. Физические основы пленочной электроники: Учеб. пособие (Петрозаводск, ПетрГУ, 1987).

Редактор Г.А. Оганесян 
The mechanism of resistance switching in films based on partially fluorinated graphene

\author{
A.I. Ivanov' ${ }^{1}$, N.A. Nebogatikova ${ }^{1}$, I.I. Kurkina ${ }^{2}$, \\ I.V. Antonova ${ }^{1,3,4}$
}

${ }^{1}$ Rzhanov Institute of Semiconductor Physics, Russian Academy of Sciences, Siberian Branch, 630090 Novosibirsk, Russia

${ }^{2}$ Ammosov North-Eastern Federal University, 677000 Yakutsk, Russia

${ }^{3}$ Novosibirsk State University, 630090 Novosibirsk, Russia

${ }^{4}$ Novosibirsk State Technical University, 630073 Novosibirsk, Russia

\begin{abstract}
The mechanism of resistance switching in films of partially fluorinated graphene (FG) was investigated. Films used were prepared on the basis of a number of graphene suspensions having different compositions and various graphene fluorination degrees. The dependences of resistance switching effect on the presence of organic additives $(N$-methylpyrrolidone, NMP and dimethylformamide, DMF) in the suspensions and the fluorination degree were experimentally investigated. It is shown that if the films are obtained from the FG flakes without organic components, the resistive switch is not observed regardless of the fluorination degree. The maximum effect about $\sim 10-20$ times, is found for films containing DMF. The physical model of the observed resistance switching of films is suggested. Origin of resistance switching effect is found to connect to the presence in the FG films of capsulated functional groups of the organic additives which are demonstrated the electrical activity. The measured current-voltage characteristics of the films are best of all described by the known model of Frenkel-Poole with activation energy of centers responsible for the conductivity about $0.08 \mathrm{eV}$. The magnitude of resistance switching also depends on the graphene fluorination degree in suspensions. The maximum effect is observed when the fluorination degree is about $\mathrm{CF}_{0.25}$. The suspensions of partially fluorinated graphene can be used for creating of device structures using 2D-printing technologies.
\end{abstract}

